Multiple Cavity Square Narrow and Broad Band Optical Filters for Infrared Region Application

Shireen Mohammed Abed

\title{
Multiple Cavity Square Narrow and Broad Band Optical Filters for Infrared Region Application
}

\author{
Shireen Mohammed Abed \\ Physics Department -Education College for Pure Sciences- Anbar University -Iraq
}

\author{
Received 4 April 2016 ; Accepted 16 August 2016
}

\section{Abstract}

In this work, theoretically optimization design of wide and narrow band pass filters have been suggested within middle- infrared region (MIR) that ranged from $9000 \mathrm{~nm}$ to $12000 \mathrm{~nm}$. For the numerical calculation, use Germanium $(\mathrm{Ge})$ as the substrate, Zinc sulfide $(\mathrm{ZnS})$ and Cryolite $\left(\mathrm{Na}_{3} \mathrm{~A}_{1 \mathrm{~F}_{6}}\right)$ as high and low refractive index respectively. The results shows that, for normal incidence yields the transmittance is high $(\mathrm{T}>99.5)$ at the center of Design wavelength $(\lambda \mathrm{o})$. Also, when the angle of incidence increase, The transmittance of electric polarization decreases and that of magnetic polarization increases , As in the case for the proposed design: Air/(LH)4LHHL(HL)4H(LH)4LHHL(HL)4(HL)4(HL)4HH(LH)4 (LH)4/Ge

$(\mathrm{TE}=96.79)$ and $(\mathrm{TM}=99.57)$ at the angle 30 .

Keywords : Transmittance, Filter, Coating, Oblique incidence. 


\section{Multiple Cavity Square Narrow and Broad Band Optical Filters} for Infrared Region Application

Shireen Mohammed Abed

$$
\begin{aligned}
& \text { مرشحات بصرية ذات حزم ضيقة وعريضة مربعة متعددة التجاويف لتطبيقات المنطقة تحث الحمراء } \\
& \text { شيرين محمد عبد } \\
& \text { جامعة الانبار - كلية التربية للعلوم الصرفةــ قسم الفيزياء } \\
& \text { الخلاصة } \\
& \text { في هذا العمل تم اقتراح تصميم نظري لمرشحات بصريه ضيقة وعريضة ضمن منطقة الطيف تحت الحمر اء المتوسطة }
\end{aligned}
$$

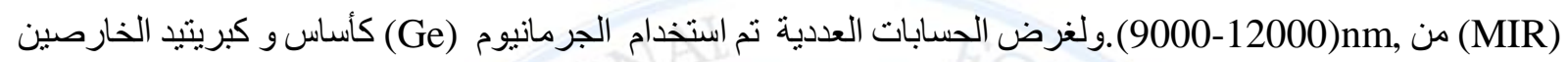

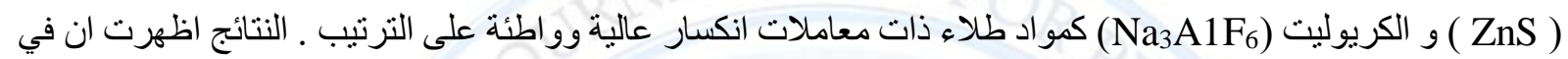

$$
\begin{aligned}
& \text { حالة السقوط العمودي نحصل على نفاذية عالية ( T> 99.5\%) عند طول موجة التصميم المركزية( } \\
& \text { وكذللك فان عند زيادة زاوية السقوط فان النفاذية الاستقطاب الكهربائي تقل و النفاذية للاستقطاب المغناطيسي تزداد ،كما هو } \\
& \text { الحال بالنسبة للتصميم المقترح } \\
& \text { (TE=94.16) Air/(LH)4LHHL(HL)4H(LH)4LHHL(HL)4(HL)4(HL)4HH(LH)4(LH)4/Ge }
\end{aligned}
$$

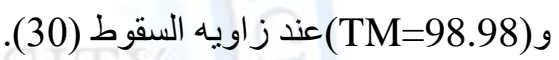

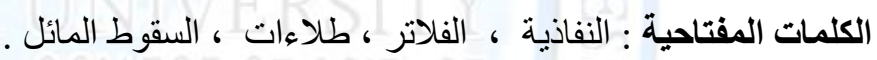

\section{$\underline{\text { Introduction }}$}

Thin-film filters as a rule comprise of various limits between different homogeneous media furthermore, it is the impact which these limits will have on an incident wave.A filter which has area of transmission limited on either side by districts of rejection is known as a band-pass filter. For the broadest band-pass filters, the most reasonable development is a mix of long wave-pass and short wave-pass filters [1]. Filters in which the essential characteristic is an unexpected change between an area of rejection and a district of transmission are known as edge filters. Edge filters are separated into two main categories, long wave-pass and shortwave pass. Thin-film filter technology gives an ordinary way to deal with delivering narrow-band infrared filters. Interference between light reflecting from each layer will add constructively for a narrow range of wavelengths, yielding a strong narrow-band reflection. Thin-film filters can accomplish highly efficient filtering [2]. The most complete data on the execution of a filter is provided by spectral transmittance $(\mathrm{T})$, reflectance $(\mathrm{R})$, absorbance (A), and optical density [3, 


\section{Multiple Cavity Square Narrow and Broad Band Optical Filters}

\section{for Infrared Region Application}

\section{Shireen Mohammed Abed}

4]. The transmittance of a thin-film gathering is independent of the direction of spread of the light $[1,5]$. Dielectric materials are preferred on the metals, because the metals have the absorption property, which increase the temperature of the coating and leads to damage it or decrease the reflectance and transmittance of the coating. While the dielectric materials have very low absorption which do not affect the reflectance and transmittance of the coating[6]. Optical spectral filters are of growing significance in today's world, where they play an important role in different fields, such as communication systems which are moving towards optical wavelengths. There are also used for wavelength separation in optical spectrometers and photometry [7], Many filtering methods are proposed based on film interference, FabryPerot $(\mathrm{F}-\mathrm{P})$ interference, guide-mode resonance Mach-Zehnder $(\mathrm{M}-\mathrm{Z})$ interferometer and photonic crystals etc.[8] . Fiber Bragg gratings, exhibit high reflectance bands Quarter-wave phase-shifted fiber Bragg gratings Serves as narrow-band transmission filters [9].The aim of the work, is to design multiple cavity square narrow and broad band filters for infrared region and study the variation of incidence angle on optical transmittance of designed filters.

\section{Theoretical Part}

Assume that a plane electromagnetic wave with wave-vector $(K)$ is incident on a plane surface separating isotropic media with refractive indices $n_{1}$ and $n_{2}$ as show in Fig. 1 [10].

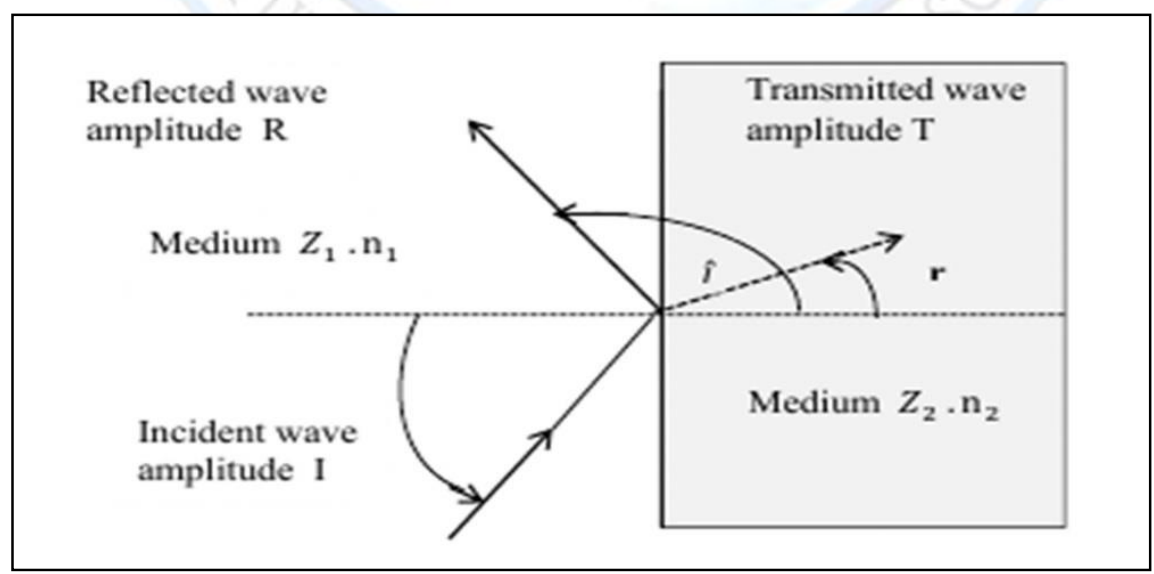

Fig.1. Incident, reflected and transmitted waves at boundary surface [10]. 


\section{Multiple Cavity Square Narrow and Broad Band Optical Filters}

\section{for Infrared Region Application}

\section{Shireen Mohammed Abed}

At normal incidence, the transmission and reflection coefficients for the two polarizations are equivalent and are given by [10]:

$$
\begin{aligned}
& \mathrm{R}=\frac{\mathrm{n}_{1}-\mathrm{n}_{2}}{\mathrm{n}_{1}+\mathrm{n}_{2}}=\frac{1-\mathrm{n}_{\mathrm{r}}}{1+\mathrm{n}_{\mathrm{r}}} \\
& \mathrm{T}=\frac{2 \mathrm{n}_{1}}{\mathrm{n}_{1}+\mathrm{n}_{2}}=\frac{2}{1+\mathrm{n}_{\mathrm{r}}}
\end{aligned}
$$

where $n_{r}$ is the relative refractive index between the two media.

The reflectance from aggregation of thin films is ascertained through the idea of optical admittance. we substitute the multilayer by a single surface which provides a admittance (Y), which is the ratio of the total tangential electric and magnetic fields and is given by [1]:

$$
Y=C / B
$$

Where

$$
\left[\begin{array}{l}
B \\
C
\end{array}\right]=\left\{\prod_{r=1}^{q}\left[\begin{array}{cc}
\cos \delta_{r} & \left(\sin \delta_{r}\right) / \eta_{r} \\
i \eta_{r} \sin \delta_{r} & \cos \delta_{r}
\end{array}\right]\right\}\left[\begin{array}{c}
1 \\
\eta_{m}
\end{array}\right]
$$

$\delta_{r}=2 \pi N d \cos \vartheta / \lambda$, where ( $\left.\delta_{\mathrm{r}}\right)$ is the phase shift , $(\lambda)$ is the wavelength in free space, ( $\mathrm{N}$ ) is the complex refractive index, $\vartheta$ is angle of incidence, (d) is physical thickness of the spacer and ( $\eta \mathrm{m})$ substrate admittance.

The order of multiplication is important. If $(q)$ is the layer next to the substrate then the order is[1]

$$
\left[\begin{array}{l}
B \\
C
\end{array}\right]=\left[M_{1}\right]\left[M_{2}\right] \ldots .\left[M_{q}\right]=\left[\begin{array}{c}
1 \\
\eta_{m}
\end{array}\right]
$$




\section{Multiple Cavity Square Narrow and Broad Band Optical Filters for Infrared Region Application}

\section{Shireen Mohammed Abed}

(M1 )refers to the matrix related with layer 1, and so on. $(\eta)$ and $(Y)$ are in similar units. As in the case of a single surface, $\left(\eta_{0}\right)$ must be real for transmittance and reflectance to have a valid meaning. With that stipulation, then [1]

$$
\begin{aligned}
& \mathrm{R}=\left(\frac{\eta_{0} \mathrm{~B}-\mathrm{C}}{\eta_{0} \mathrm{~B}+\mathrm{C}}\right)\left(\frac{\eta_{0} \mathrm{~B}-\mathrm{C}}{\eta_{0} \mathrm{~B}+\mathrm{C}}\right)^{*} \\
& T=\frac{4 \eta_{0} R_{e}\left(\eta_{M}\right)}{\left(\eta_{0} B+C\right)\left(\eta_{0} B+C\right)^{*}}
\end{aligned}
$$

There are many various methods of describing the performance of optical coatings and filters. The fundamental equation that all filters performance depend on it is [11]

$$
\mathrm{R}+\mathrm{T}+\mathrm{A}=1
$$

For example, transmission and reflection filters intended for visual applications . Referring to Fig .2. at a wavelength $\lambda$ the normal incidence spectral transmittance $T(\lambda)$ of a filter placed between two semi-infinite media is equal to:

$$
\mathrm{T}(\lambda)=\mathrm{IT}(\lambda) / \mathrm{I}_{\mathrm{o}}(\lambda)
$$

where, $T(\lambda)$ is the light intensity transmitted at that wavelength by the filter, Io $(\lambda)$ is the incident intensity of the light at the same wavelength [11].In this paper, We design a computer program (PC) using MATLAB version (7) to calculate transmission for Optical Filters ,this program depends on suggestion designs, refractive index of (coating) materials, incident angle and number of layers as shows in Flowchart A-1. 


\section{Multiple Cavity Square Narrow and Broad Band Optical Filters} for Infrared Region Application

Shireen Mohammed Abed

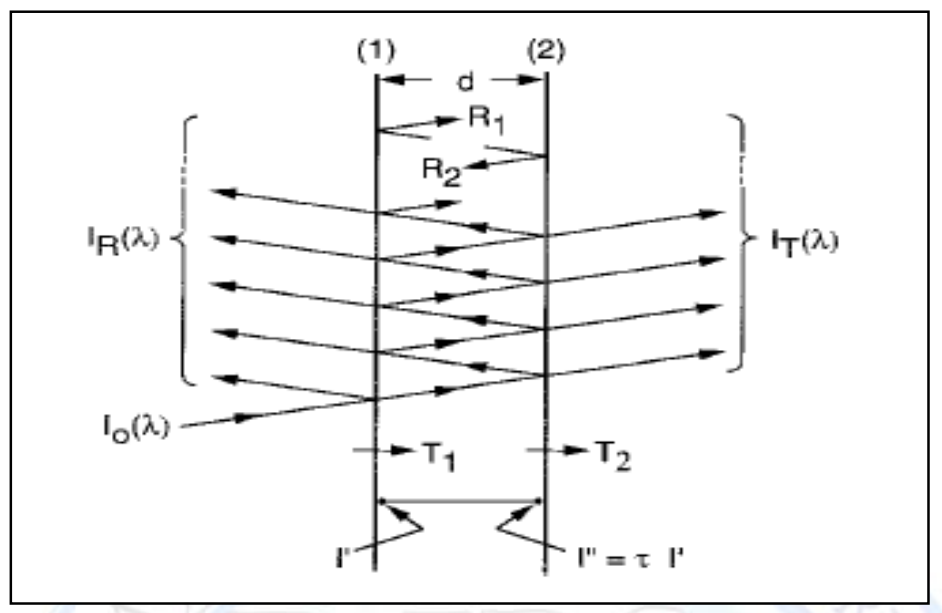

Fig.2. the incident light on a plane-parallel [11].

\section{$\underline{\text { Results and Discussion }}$}

The proposed design that used in this work illustrated in Table (1) which using a computer program in MATLAB version 7 to calculate Transmittance within middle- infrared region (MIR) that ranged from $9000 \mathrm{~nm}$ to $12000 \mathrm{~nm}$. at designed wavelength $\lambda_{0}=10600 \mathrm{~nm}$. For the numerical calculation, we used coating consist from Zinc sulfide $(\mathrm{ZnS})(\mathrm{n}=2.2)$, Cryolite (Na3A1F6) $(n=1.35)$ as materials and Germanium $(n=4)$ as the substrate. Fig.3. shows the transmission spectra as the function of wavelength of coating ( $\mathrm{ZnS}, \mathrm{Na3A} 1 \mathrm{~F} 6)$ and (Ge) as the substrate for three different proposed designs and their results shows in Table (1).

Table 1: Transmittance values and FWHM for three different suggestion designs at normal incidence.

\begin{tabular}{|c|c|c|}
\hline Suggestion design & FWHM & Transmittance \\
\hline $\operatorname{Air} /(\mathrm{HL})^{\mathrm{N}}(\mathrm{HL})^{\mathrm{N}} \mathrm{HH}(\mathrm{LH})^{\mathrm{N}}(\mathrm{LH})^{\mathrm{N}} / \mathrm{Ge}$ & $660 \mathrm{~nm}$ & $\% 64$ \\
\hline $\operatorname{Air} /(\mathrm{LH})^{\mathrm{N}} \operatorname{LHHL}(\mathrm{HL})^{\mathrm{N}}(\mathrm{HL})^{\mathrm{N}}(\mathrm{HL})^{\mathrm{N}} \mathrm{HH}(\mathrm{LH})^{\mathrm{N}}(\mathrm{LH})^{\mathrm{N}} / \mathrm{Ge}$ & $530 \mathrm{~nm}$ & $\% 64$ \\
\hline $\begin{array}{c}\left.\operatorname{Air} /(\mathrm{LH})^{\mathrm{N}} \operatorname{LHHL}(\mathrm{HL})^{\mathrm{N}} \mathrm{H}(\mathrm{LH})^{\mathrm{N}} \text { LHHL(HL) }\right)^{\mathrm{N}}(\mathrm{HL})^{\mathrm{N}}(\mathrm{HL})^{\mathrm{N}} \\
\operatorname{HH}(\mathrm{LH})^{\mathrm{N}}(\mathrm{LH})^{\mathrm{N}} / \mathrm{Ge}\end{array}$ & $470 \mathrm{~nm}$ & $99.08 \%$ \\
\hline
\end{tabular}


Multiple Cavity Square Narrow and Broad Band Optical Filters for Infrared Region Application

Shireen Mohammed Abed

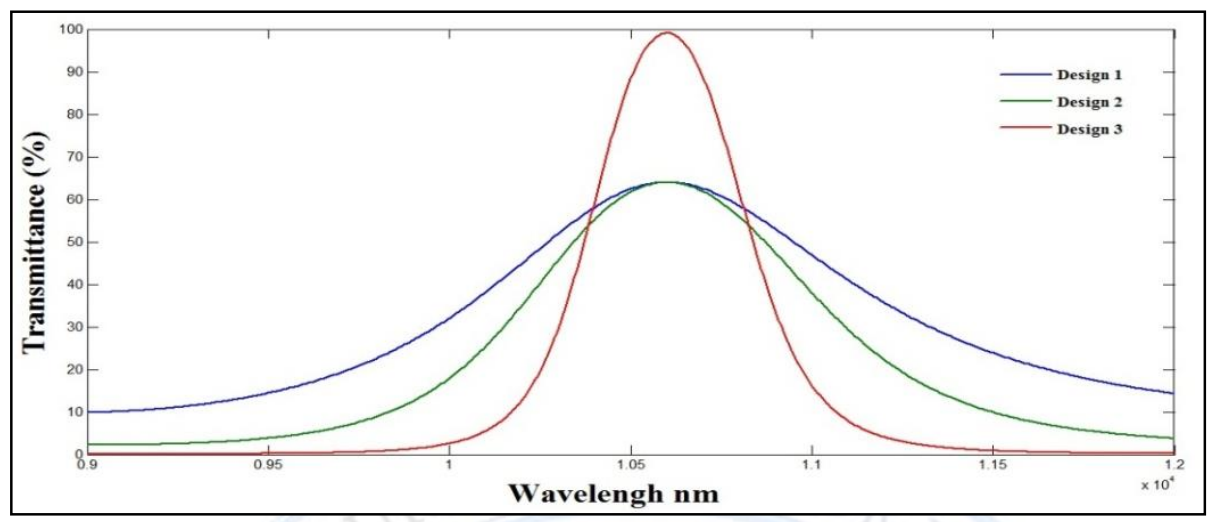

Fig.3. the transmission spectra of $(\mathrm{ZnS}$, Cryolite (Na3A1F6), on the substrata(Ge) for three suggestion design as a function to the wavelength at normal incidence:

1- Design (1) Air/(HL) $)^{\mathrm{N}}(\text { HL) })^{\mathrm{N}} \mathrm{HH}(\mathrm{LH})^{\mathrm{N}}(\mathrm{LH})^{\mathrm{N}} / \mathrm{Ge}$

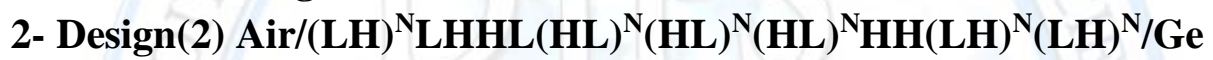

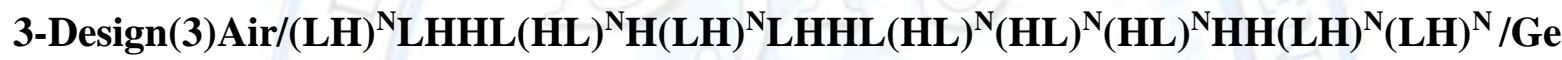

Where the difference appears in the number of layers of the design and also the difference in the number of cavity (space layer) $(\mathrm{HH})$. Because of the difference the bandwidth was affected while transmittance in the first and second design was equal, because the number of layers was not enough to affect the transmittance while it was enough to change the bandwidth . When it increases the value of similar mutually layers of high and low refractive indices $(\mathrm{N})$ For the suggested design:

\section{$\operatorname{Air} /(\text { LH })^{\mathrm{N}}$ LHHL $(\text { HL })^{\mathrm{N}}$ H(LH) $)^{\mathrm{N}}$ LHHL(HL) $)^{\mathrm{N}}(\text { HL })^{\mathrm{N}}(\text { HL })^{\mathrm{N}}$ HH(LH) ${ }^{\mathrm{N}}(\text { LH })^{\mathrm{N}} / \mathrm{Ge}$}

Will find the value of FWHM (full width at half maximum ) less and this clear in Fig. (4 and 5 ) and table (2) 


\section{DIYALA JOURNAL FOR PURE SCIENCES}

Multiple Cavity Square Narrow and Broad Band Optical Filters for Infrared Region Application

Shireen Mohammed Abed

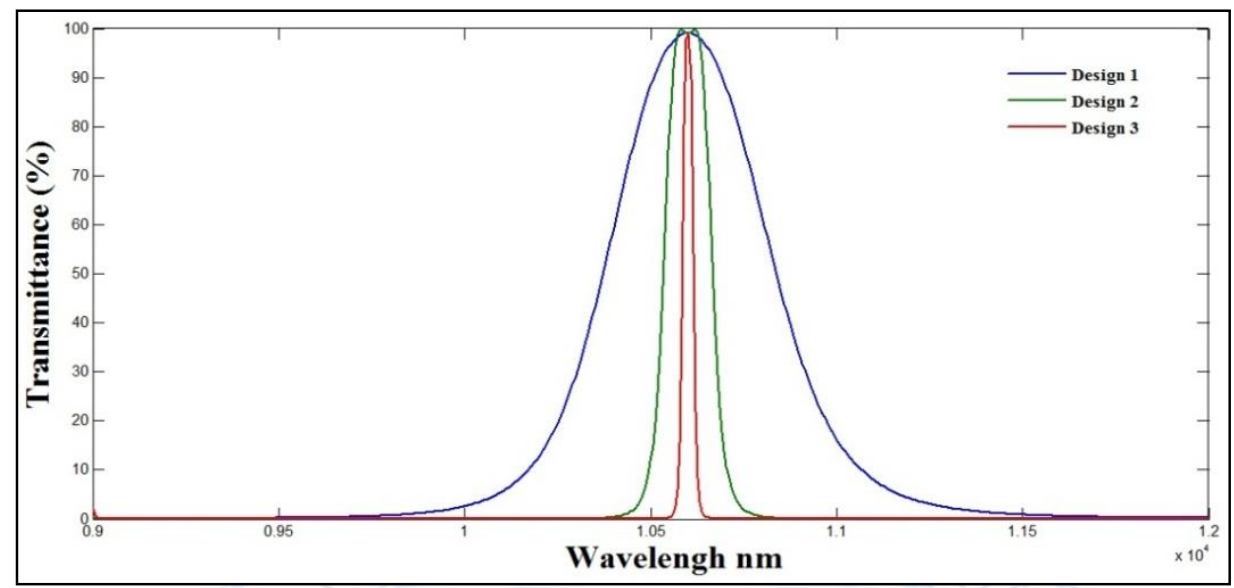

Fig. 4. The transmission spectra of ( $\mathrm{ZnS}$, Cryolite (Na3A1F6) on the substrata(Ge) at normal incidence When we increase $\mathbf{N}$ :

1- Design (1) Air/(LH)LHHL(HL)H(LH)LHHL(HL)(HL)(HL)HH(LH)(LH)/Ge

2- Design(2)Air/(LH $)^{2}$ LHHL(HL) $)^{2}$ H(LH $)^{2}$ LHHL(HL) $)^{2}(\text { HL })^{2}(\text { HL })^{2}$ HH(LH $)^{2}(\text { LH })^{2} / G$

3- Design(3)Air/(LH) $)^{3}$ LHHL(HL) ${ }^{3}$ H(LH) ${ }^{3}$ LHHL(HL) $)^{3}(\text { HL })^{3}(\text { HL })^{3}$ HH(LH $)^{3}(\text { LH })^{3} / G$

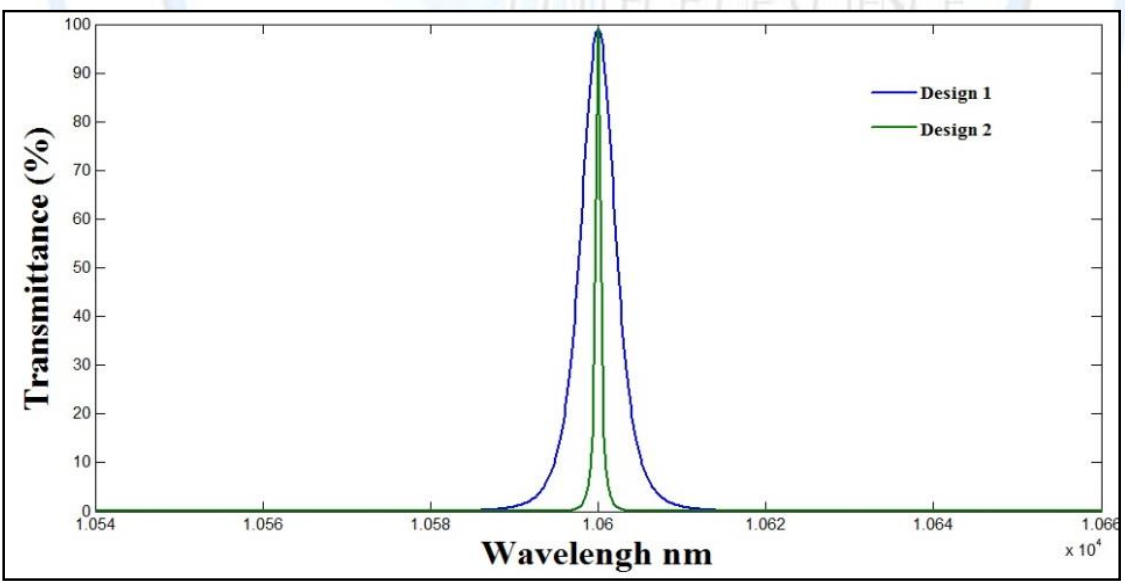

Fig. 5. The transmission spectra of $(\mathrm{ZnS}$, Cryolite (Na3A1F6) on the substrata(Ge) at normal incidence for $\mathrm{N}=4$ and $\mathrm{N}=5$ :

1- Design (1) Air/(LH) ${ }^{4}$ LHHL(HL) $\left.{ }^{4} \mathrm{H}(\mathrm{LH})^{4} \mathrm{LHHL}_{(\mathrm{HL}}\right)^{4}(\mathrm{HL})^{4}(\mathrm{HL})^{4} \mathrm{H}(\mathrm{LH})^{4}(\mathrm{LH})^{4} / \mathrm{Ge}$

2- Design(2) Air/(LH) ${ }^{5}$ LHHL(HL) ${ }^{5}$ H(LH) ${ }^{5}$ LHHL(HL $)^{5}(H L)^{5}(H L)^{5}$ HH(LH $\left(\right.$ LH $^{5}(\mathrm{LH})^{5} / \mathrm{Ge}$ 
Multiple Cavity Square Narrow and Broad Band Optical Filters for Infrared Region Application

Shireen Mohammed Abed

Table 2: Transmittance and FWDM for suggestion designs in normal incidence

\begin{tabular}{|c|c|c|}
\hline Suggestion design & FWHM & Transmittance \\
\hline $\begin{array}{c}\text { Air/(LH)LHHL(HL)H(LH)LHHL(HL)(HL)(HL)H } \\
\text { H(LH)(LH)/Ge }\end{array}$ & $470 \mathrm{~nm}$ & $\% 99.08$ \\
\hline $\begin{array}{c}\text { Air/(LH })^{2} \mathrm{LHHL}(\mathrm{HL})^{2} \mathrm{H}(\mathrm{LH})^{2} \mathrm{LHHL}(\mathrm{HL})^{2}(\mathrm{HL})^{2}(\mathrm{H} \\
\mathrm{L})^{2} \mathrm{HH}(\mathrm{LH})^{2}(\mathrm{LH})^{2} / \mathrm{Ge}\end{array}$ & $130 \mathrm{~nm}$ & $99.15 \%$ \\
\hline $\begin{array}{c}\text { Air/(LH })^{3} \mathrm{LHHL}(\mathrm{HL})^{3} \mathrm{H}(\mathrm{LH})^{3} \mathrm{LHHL}(\mathrm{HL})^{3}(\mathrm{HL})^{3}(\mathrm{H} \\
\mathrm{L})^{3} \mathrm{HH}(\mathrm{LH})^{3}(\mathrm{LH})^{3} / \mathrm{Ge}\end{array}$ & $30 \mathrm{~nm}$ & $98.88 \%$ \\
\hline $\begin{array}{c}\text { Air/(LH })^{4} \mathrm{LHHL}(\mathrm{HL})^{4} \mathrm{H}(\mathrm{LH})^{4} \mathrm{LHHL}(\mathrm{HL})^{4}(\mathrm{HL})^{4}(\mathrm{H} \\
\mathrm{L})^{4} \mathrm{HH}(\mathrm{LH})^{4}(\mathrm{LH})^{4} / \mathrm{Ge}\end{array}$ & $4.8 \mathrm{~nm}$ & $99.05 \%$ \\
\hline $\begin{array}{c}\text { Air/(LH })^{5} \mathrm{LHHL}(\mathrm{HL})^{5} \mathrm{H}(\mathrm{LH})^{5} \mathrm{LHHL}(\mathrm{HL})^{5}(\mathrm{HL})^{5}(\mathrm{H} \\
\mathrm{L})^{5} \mathrm{HH}(\mathrm{LH})^{5}(\mathrm{LH})^{5} / \mathrm{Ge}\end{array}$ & $0.9 \mathrm{~nm}$ & $99.1 \%$ \\
\hline
\end{tabular}

. It is clear that the (FWHM) decreases with increase the number of spacer and the number of layer as shown in Table(3).

Table 3 : Type of band pass and FWHM of the suggestion designs.

\begin{tabular}{|c|c|c|}
\hline Suggestion design & FWH & Band type \\
& M & \\
\hline Air/(LH)LHHL(HL)H(LH)LHHL(HL)(HL) & 470 & Wide \\
HL $) H H(L H)(L H) / G e$ & $\mathrm{~nm}$ & \\
\hline Air/(LH $)^{2} \mathrm{LHHL}(\mathrm{HL})^{2} \mathrm{H}(\mathrm{LH})^{2} \mathrm{LHHL}(\mathrm{HL})^{2}(\mathrm{H}$ & 130 & Wide \\
$\mathrm{L})^{2}(\mathrm{HL})^{2} \mathrm{HH}(\mathrm{LH})^{2}(\mathrm{LH})^{2} / \mathrm{Ge}$ & $\mathrm{nm}$ & \\
\hline Air/(LH $)^{3} \mathrm{LHHL}(\mathrm{HL})^{3} \mathrm{H}(\mathrm{LH})^{3} \mathrm{LHHL}(\mathrm{HL})^{3}(\mathrm{H}$ & $30 \mathrm{~nm}$ & Wide \\
$\mathrm{L})^{3}(\mathrm{HL})^{3} \mathrm{HH}(\mathrm{LH})^{3}(\mathrm{LH})^{3} / \mathrm{Ge}$ & & \\
\hline Air/(LH $)^{4} \mathrm{LHHL}(\mathrm{HL})^{4} \mathrm{H}(\mathrm{LH})^{4} \mathrm{LHHL}(\mathrm{HL})^{4}(\mathrm{H}$ & 4.8 & Narrow \\
$\mathrm{L})^{4}(\mathrm{HL})^{4} \mathrm{HH}(\mathrm{LH})^{4}(\mathrm{LH})^{4} / \mathrm{Ge}$ & $\mathrm{nm}$ & \\
\hline Air/(LH $)^{5} \mathrm{LHHL}(\mathrm{HL})^{5} \mathrm{H}(\mathrm{LH})^{5} \mathrm{LHHL}(\mathrm{HL})^{5}(\mathrm{HL})$ & $0.9 \mathrm{~nm}$ & Ultra-Narrow \\
${ }^{5}(\mathrm{HL})^{5} \mathrm{HH}(\mathrm{LH})^{5}(\mathrm{LH})^{5} / \mathrm{Ge}$ & & \\
\hline
\end{tabular}




\section{Multiple Cavity Square Narrow and Broad Band Optical Filters} for Infrared Region Application

\section{Shireen Mohammed Abed}

The table (1) shows three different designs. The dielectric layer replace the spacer. the old expression for such a layer is the spacer layer but the tendency in these days is to call it the cavity layer. Now taking the proposed designs;

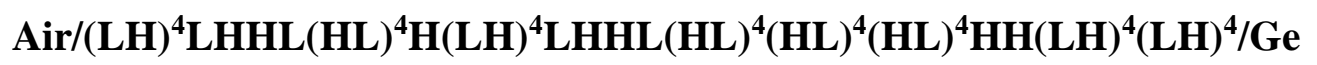

and

$$
\operatorname{Air} /(\mathrm{LH})^{5} \mathrm{LHHL}(\mathrm{HL})^{5} \mathrm{H}(\mathrm{LH})^{5} \mathrm{LHHL}(\mathrm{HL})^{5}(\mathrm{HL})^{5}(\mathrm{HL})^{5} \mathrm{HH}(\mathrm{LH})^{5}(\mathrm{LH})^{5} / \mathrm{Ge}
$$

and change the incident angel to know the effect on the transmittance and Bandwidth . The transmittance of electric polarization decreases and that of magnetic polarization increases when the incident angle increases . and therefore the transmittance bandwidth of magnetic polarization is wider and that of electric polarization is narrower. Figs $(6,7,8$ and 9$)$. show the center wavelengths of both transmission bands shift to shorter wavelength region when the incident angel increases and their results shows in Table (4) .

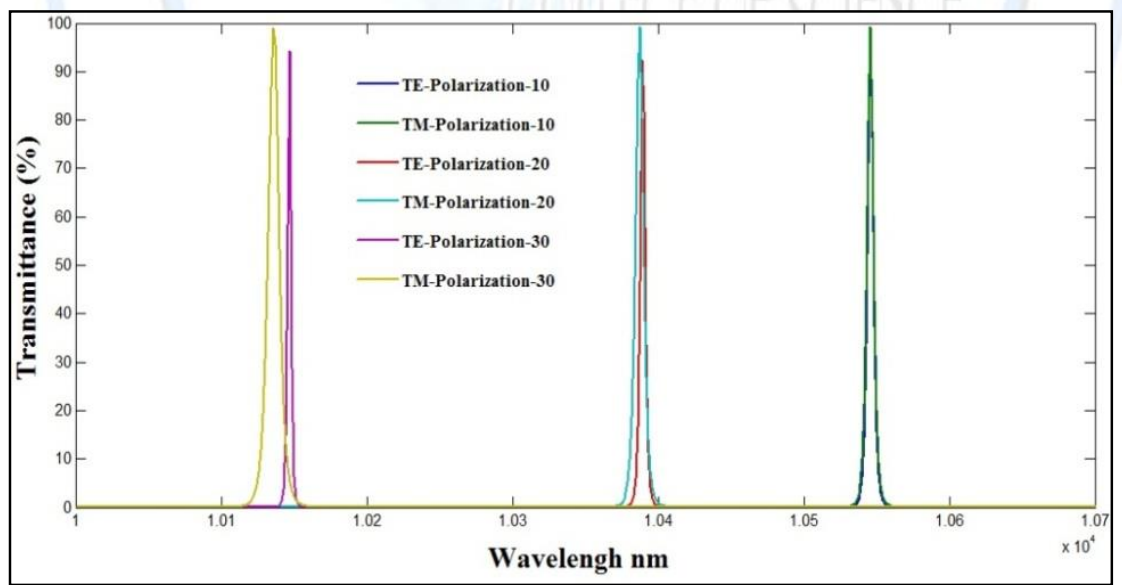

Fig.6. the transmission spectra of $(\mathrm{ZnS}$, Cryolite (Na3A1F6) on the substrata(Ge) of TE and TM modes as a function of wavelength at non-normal incidence $\left(\theta=10^{\circ}, 20^{\circ}\right.$ and $30^{\circ}$ ) for the design:

Air $/(\text { LH })^{4}$ LHHL $(\text { HL })^{4}$ H(LH) $)^{4}$ LHHL $(H L)^{4}(H L)^{4}(H L)^{4} H H(L H)^{4}(\text { LH })^{4} /$ Ge 
Multiple Cavity Square Narrow and Broad Band Optical Filters for Infrared Region Application

Shireen Mohammed Abed

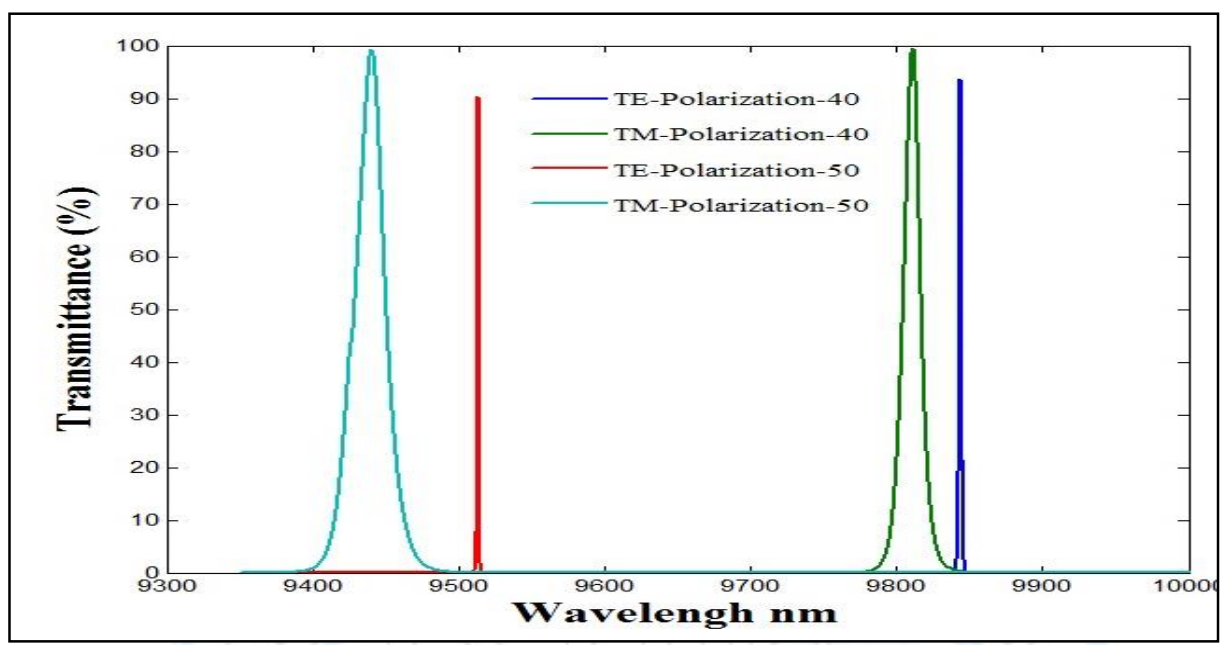

Fig.7.: the transmission spectra of $(\mathrm{ZnS}$, Cryolite (Na3A1F6) on the substrata(Ge) of TE and TM modes as a function of wavelength at non-normal incidence $\left(\theta=40^{\circ}\right.$ and $\left.50^{\circ}\right)$ for the design :Air/(LH) ${ }^{4} \mathrm{LHHL}(\mathrm{HL})^{4} \mathrm{H}(\mathrm{LH})^{4} \mathrm{LHHL}(\mathrm{HL})^{4}(\mathrm{HL})^{4}(\mathrm{HL})^{4} \mathrm{HH}(\mathrm{LH})^{4}(\mathrm{LH})^{4} / \mathrm{Ge}$

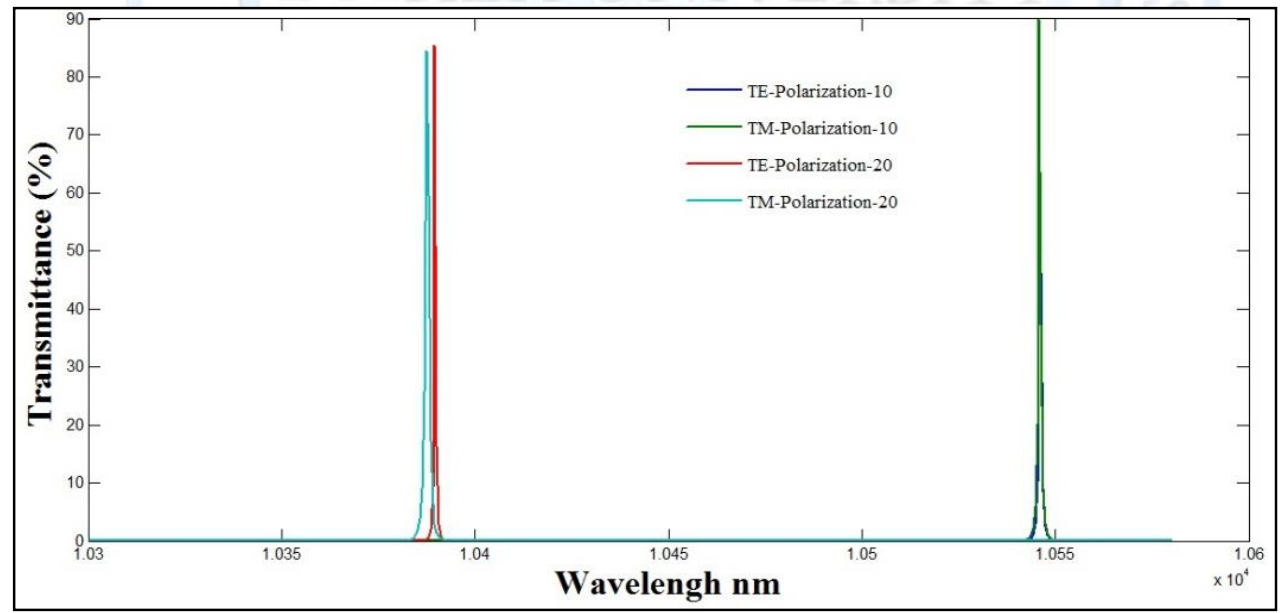

Fig.8.the transmission spectra of $(\mathrm{ZnS}$, Cryolite (Na3A1F6) on the substrata(Ge) of TE and TM modes as a function of wavelength at non-normal incidence $\left(\theta=10^{\circ}\right.$ and $\left.20^{\circ}\right)$ for the design: Air/(LH) ${ }^{5} \mathrm{LHHL}(\mathrm{HL})^{5} \mathrm{H}(\mathrm{LH})^{5} \mathrm{LHHL}(\mathrm{HL})^{5}(\mathrm{HL})^{5}(\mathrm{HL})^{5} \mathrm{HH}(\mathrm{LH})^{5}(\mathrm{LH})^{5} / \mathrm{Ge}$ 
Multiple Cavity Square Narrow and Broad Band Optical Filters

for Infrared Region Application

Shireen Mohammed Abed

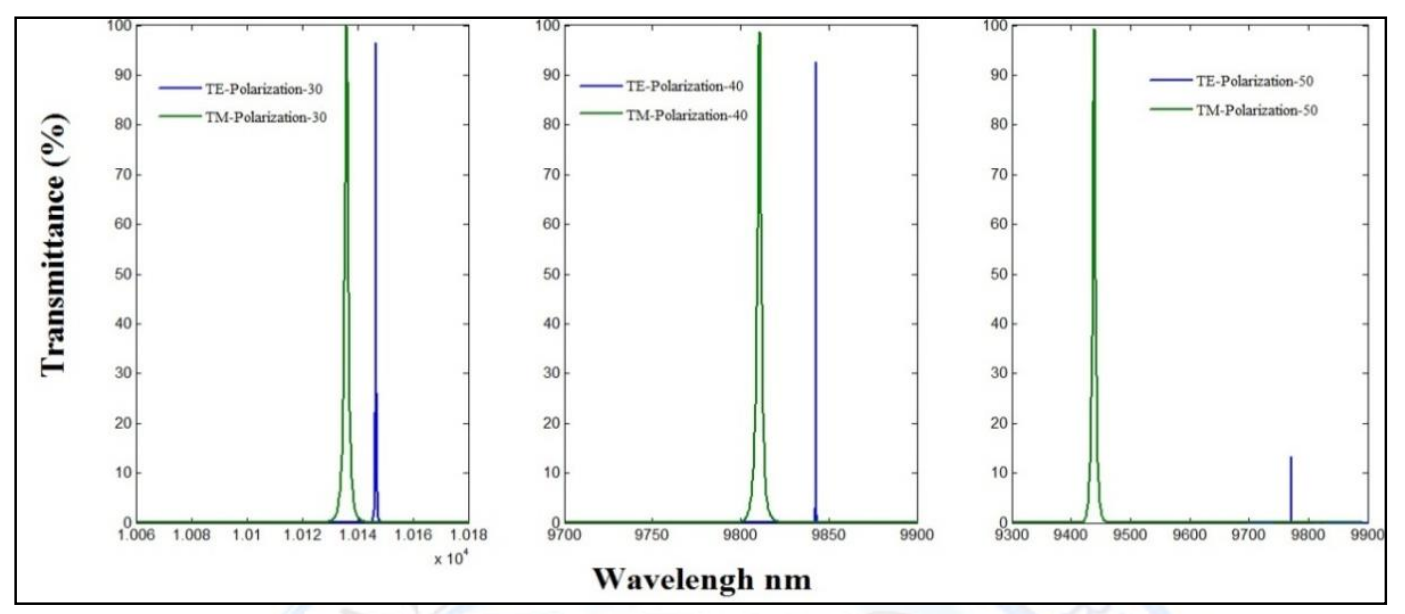

Fig.9. the transmission spectra of $(\mathrm{ZnS}$, Cryolite (Na3A1F6) on the substrata(Ge) of TE and TM modes as a function of wavelength at non-normal incidence $\left(\theta=30^{\circ}, 40^{\circ}\right.$ and $50^{\circ}$ ) for the design: $\operatorname{Air} /(\mathrm{LH})^{5} \mathrm{LHHL}(\mathrm{HL})^{5} \mathrm{H}(\mathrm{LH})^{5} \mathrm{LHHL}(\mathrm{HL})^{5}(\mathrm{HL})^{5}(\mathrm{HL})^{5}$ HH(LH) $)^{5}(\mathrm{LH})^{5} / \mathrm{Ge}$.

Table 4: Transmittance and FWHM for TE and TM modes at non-normal incidence

\begin{tabular}{|c|c|c|c|c|c|}
\hline Suggestion design & $\begin{array}{c}\text { Angle } \\
\text { incidence }\end{array}$ & $\begin{array}{c}\text { FWHM } \\
\text { for TE } \\
(\mathbf{n m})\end{array}$ & $\begin{array}{c}\text { The Transmittance } \\
\text { of the electric } \\
\text { polarization } \\
\text { TE }\end{array}$ & $\begin{array}{c}\text { FWHM } \\
\text { for TM } \\
\text { (nm) }\end{array}$ & $\begin{array}{c}\text { The Transmittance } \\
\text { of the magnetic } \\
\text { polarization } \\
\text { TM }\end{array}$ \\
\hline \multirow{2}{*}{$\begin{array}{c}\text { Air/(LH)4LHHL(HL } \\
\text { )4H(LH)4LHHL(HL) }\end{array}$} & 10 & 5 & 99 & 5.5 & 99.3 \\
\cline { 2 - 6 } )4(HL)4(HL)4HH(L & 20 & 2.8 & 96.86 & 6.4 & 99.35 \\
\cline { 2 - 6 } H)4(LH)4/Ge & 30 & 2.7 & 96.79 & $\mathbf{8 . 6}$ & 99.57 \\
\cline { 2 - 6 } & 40 & 1.6 & 94.31 & 14.9 & 100 \\
\cline { 2 - 6 } & $\mathbf{5 0}$ & 1.2 & 90.1 & 23.9 & 100 \\
\hline
\end{tabular}

\section{Conclusions}

From the above outcome, one can conclude that the transmittance for coating depends on number of layers, the coating type and angle of incidence. The best coating at $(10600 \mathrm{~nm})$ for the Proposed design ; Air/(LH)L(HH)L(HL)H(LH)L(HH)L (HL)/Ge is ( $\mathrm{ZnS}$, Cryolite (Na3A1F6), on the substrata of (Ge) which gives ( $\mathrm{T}=99.05 \%)$ at normal incident. Because there are important applications for Thin film interference filters, especially the narrow and ultra- 


\section{Multiple Cavity Square Narrow and Broad Band Optical Filters}

\section{for Infrared Region Application}

\section{Shireen Mohammed Abed}

narrow band-pass filters are very useful components in realizing a technique of sending signals of several different wavelengths of light into the fiber at the same time (WDM). We choose the best type of Bandwidth ( Narrow Band and Ultra-Narrow Band ) when increases the value of similar alternating layers of high and low refractive indices $\mathrm{N}=(4$ and 5).

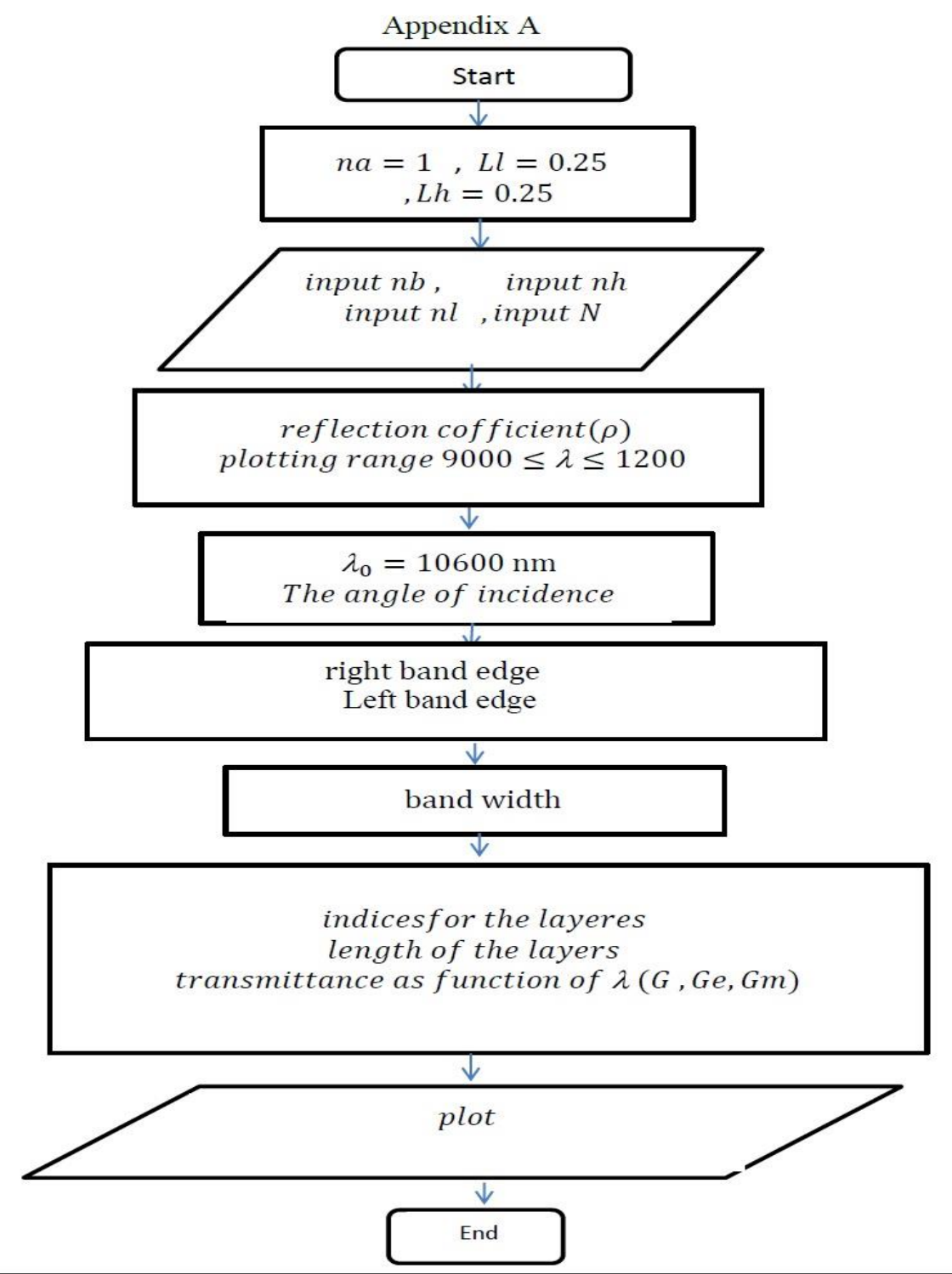

Flowchart A-1 : A schematically station of the different part of the program to calculate the transmission for Optical Filters within middle-infrared region (MIR) that ranged from $9000 \mathrm{~nm}$ to $12000 \mathrm{~nm}$. at 


\title{
Multiple Cavity Square Narrow and Broad Band Optical Filters
} for Infrared Region Application

\author{
Shireen Mohammed Abed
}

\section{$\underline{\text { References }}$}

1. Thin-Film Optical Filters , Third Edition , 1999 ,H. A. Macleod ,University Of Arizona ,Top

2. Laser-Line Rejection or Transmission Filters Based on Surface Structures Built on Infrared Transmitting Materials , 2005 , Douglas , Hobbs , Window and Dome Technologies and Materials IX, volume 5786, 319 , doi:10.1117/12.604537

3. Handbook Of Optics, Third Edition, 1995, M. Bass , vol.1, Sponsored by the Optical Society Of America, The McGraw-Hill Companies.

4. Optimization Design of Band Pass Filter in The Infrared Region, 2015, Saeed N. Turk, International Journal of Emerging Trends \& Technology in Computer Science (IJETTCS), Volume 4, Issue 2 ISSN 2278-6856.

5. The Physics of Thin Film Optical Spectra. 2005, O. Stenzel., An Introduction SpringerVerlag Berlin Heidelberg .

6. Modern Optics, 1990, R. D. Guenther, Canada, John Wiley and Sons .

7. Self-Assembled Multilayer Dielectric Spectral Filters ,2001, A. Chandron , Virginia University, MSc thesis.

8. Narrow band optical filter using Goos - Hänchen shift in a cascaded waveguide structure,2014, Mincheng Tang, Maowu Ran, Fan Chen, Xianping Wang, Honggen Li, Xianfeng Chen and ZhuangqiCao, 55 ,42-45, Optics \&LaserTechnology.

9. Electromagnetic Waves and Antennas .1999-2010, J. Sophocles, Rutgers University .

10. Optical Physics, Fourth Edition, 2011 , A. Lipson, S. G. Lipson and H. Lipson, Frs, New York, United States of America by Cambridge University Press .

11. A Theoretical Design and Study of Different Multi-Cavity Interference Filters, 2009, Husam Sabeeh Al-Arab , Al-Mustansiriyah University . 